\title{
Analisis Komposisi dan Distribusi Batu Empedu di Laboratorium Fakultas Kedokteran Universitas Indonesia (FKUI) Jakarta
}

\section{Analysis of The Composition and Distribution of Gallstones in Faculty of Medicine Universitas Indonesia (FMUI) Laboratory Jakarta}

\author{
Tri Retno Yova Meidina ${ }^{1}$, Ninik Mudjihartini ${ }^{2}$, Dwirini Retno Gunarti ${ }^{2}$, Yulhasri $^{2}$, Syarifah $^{2}$ \\ Dewi $^{2}$, Novi Silvia Hardiany ${ }^{2 *}$ \\ ${ }^{1}$ Prodi Pendidikan Dokter, Fakultas Kedokteran, Universitas Indonesia, Jakarta, 10430, Indonesia \\ ${ }^{2}$ Departemen Biokimia dan Biologi Molekuler, Fakultas Kedokteran, Universitas Indonesia, Jakarta, 10430, \\ Indonesia \\ *E-mail: novi.silvia@ui.ac.id; novish98@gmail.com
}

\begin{abstract}
Abstrak
Batu empedu merupakan penyakit yang banyak ditemukan di Indonesia. Analisis komposisi batu empedu penting untuk mengetahui penyebab, dasar metabolisme pembentukannya, faktor risiko, serta untuk edukasi diet terhadap pasien. Komposisi batu empedu tersebut dapat dipengaruhi oleh berbagai faktor termasuk usia dan jenis kelamin. Sampai saat ini belum terdapat data analisis komposisi dan distribusi batu empedu di Jakarta. Dengan demikian, penelitian ini bertujuan untuk menganalisis komposisi dan distribusi batu empedu yang dihubungkan dengan usia dan jenis kelamin. Penelitian ini merupakan penelitian cross-sectional menggunakan 230 data sekunder hasil analisis komposisi batu empedu di Laboratorium Biokimia dan Biologi Molekuler FKUI dalam periode 3 tahun terakhir (tahun 2017 - 2019). Analisis batu dilakukan dengan uji Salkowski untuk menilai kolesterol serta uji kalsium, karbonat, Fe, pigmen empedu, dan fosfat. Hasil penelitian menunjukkan bahwa batu empedu sebesar 1,3\% merupakan batu murni dan 98,7\% merupakan batu campuran. Komposisi terbanyak pada batu campuran yaitu kolesterol (83,91\%). Batu empedu paling banyak ditemukan pada perempuan kelompok usia 40-49 tahun (27\%). Terdapat hubungan komposisi kolesterol dengan usia $(p<0,05)$ namun tidak terdapat hubungan $(p>0,05)$ dengan jenis kelamin $(p>0,05)$. Kesimpulan dari penelitian ini yaitu kolesterol merupakan penyusun komposisi batu empedu yang terbanyak yang berhubungan dengan usia, namun tidak berhubungan dengan jenis kelamin.
\end{abstract}

Kata kunci: Batu Empedu, Distribusi, Komposisi, Kolesterol

\begin{abstract}
Gallstones are a disease that is commonly found in Indonesian. Analysis of the composition of gallstones is important to determine the etiology, the metabolic basis of its formation, risk factors, and to educate for the patient's diet. The composition of gallstones can be influenced by various factors including age and sex. Until now there is no data analysis of the composition and distribution of gallstones in Jakarta. Thus, this study aims to analyze the composition and distribution of gallstones that are associated with age and sex. This study is a cross-sectional study using 230 secondary data from the analysis of the composition of gallstones in the Laboratory of Biochemistry and Molecular Biology of FMUI in the last 3 years period (2017 - 2019). Stone analysis was carried out with the Salkowski test to assess cholesterol and also calcium, carbonate, Fe, bile pigment, and phosphate assays. The results showed that $1.3 \%$ gallstones were pure stones and $98.7 \%$ were mixed stones. The most composition in mixed stones is cholesterol (83.91\%). Gallstones are most commonly found in women in the age group of 40-49 years (27\%). There is a correlation between cholesterol composition with age $(p<0.05)$ but there is no relationship $(p>0.05)$ with gender $(p>0.05)$. This study concluded that cholesterol was the most common constituent of gallstone. Its levels increased with age and did not differ significantly between genders.
\end{abstract}

Keywords: Gallstone, Composition, Distribution, Cholesterol 
Pendahuluan

Pada awalnya, batu empedu merupakan penyakit yang paling banyak ditemukan di negara Barat dan sangat jarang ditemukan di negara berkembang. Namun dengan perubahan sosial ekonomi di negara berkembang menyebabkan angka kejadian batu empedu mulai meningkat. ${ }^{1}$ Komposisi batu empedu dari setiap negara akan berbeda oleh karena faktor usia, jenis kelamin, diet, sosialekonomi, dan demografi. Menurut penelitian yang dilakukan di Arab ditemukan komposisi kolesterol dalam batu empedu lebih banyak ditemukan pada perempuan dibandingkan dengan laki-laki. Selain itu komposisi batu empedu juga dipengaruhi oleh usia. Analisis komposisi batu empedu menjadi sangat penting untuk dapat memberikan informasi penting terkait penyebab, dasar metabolisme pembentukannya, dan menentukan faktor risiko yang memengaruhi individu tertentu, serta dapat bermanfaat untuk edukasi diet terhadap pasien. ${ }^{2,3}$ Di Nepal, batu empedu ditemukan paling banyak pada pasien yang berumur 30 - 39 tahun, yaitu sekitar 32,5\%. Namun pada penelitian tersebut tidak menjelaskan mengenai komposisi batu empedu yang ditemukan. $^{4}$

Pada studi epedimiologi populasi Amerika, insiden batu empedu terjadi sekitar $10 \%-15 \%$ dari populasi orang dewasa atau setara dengan $20-25$ juta orang Amerika memiliki batu empedu. ${ }^{5}$ Pada survey yang dilakukan di Amerika dari tahun 2013-2016 menunjukkan bahwa sekitar $36,6 \%$ orang dewasa mengonsumsi makanan cepat saji pada hari tertentu. Makanan cepat saji berkaitan erat dengan tingginya pemasukan kalori, lemak, dan rendahnya serat. Tingginya kalori, lemak, dan rendahnya serat memiliki hubungan dengan kejadian batu empedu. ${ }^{6,7}$
Berdasarkan penelitian yang dilakukan di Taiwan, prevalensi batu empedu sekitar $4.3 \%-10.7 \% .^{8}$ Dengan adanya perkembangan dan pertumbuhan ekonomi dari negara-negara Asia mulai memunculkan perubahan-perubahan dalam konsumsi makanan menjadi pola konsumsi makanan barat. Perubahan menjadi pola makanan barat dapat berkontribusi terhadap peningkatan obesitas di Cina. Obesitas juga merupakan salah satu faktor risiko terjadinya peningkatan kejadian batu empedu. ${ }^{7,9}$

Sementara di Indonesia belum terdapat data dari Riset Kesehatan Dasar (Riskesdas) maupun Kementerian Kesehatan (Kemenkes) mengenai prevalensi batu empedu. Namun ada beberapa penelitian yang dilakukan di beberapa rumah sakit daerah di Indonesia. Salah satunya, yaitu penelitian yang dilakukan di Rumah Sakit Umum Dr. Soedarso, Pontianak menyebutkan bahwa pada periode Januari 2010 hingga Desember 2011 terdapat 63 pasien perempuan batu empedu dan 36 pasien laki-laki batu empedu yang didiagnosis dan dirawat di Rumah Sakit Umum Dr. Soedarso. ${ }^{10}$ Akan tetapi dari penelitian tersebut tidak menyebutkan komposisi batu yang ditemukan. Dengan demikian penelitian ini bertujuan untuk mengetahui gambaran analisis komposisi dan distribusi batu empedu dan hubungannya dengan usia serta jenis kelamin pada penderita batu empedu di Laboratorium Fakultas Kedokteran Universitas Indonesia (FKUI) Jakarta.

\section{Metode}

Penelitian menggunakan desain studi cross-sectional untuk mengetahui analisis komposisi dan distribusi batu empedu serta hubungannya dengan usia dan jenis kelamin. Sampel penelitian menggunakan 230 data sekunder meliputi hasil analisis 
komposisi batu empedu, jenis kelamin, dan usia pasien dari catatan medis pemeriksaan analisis komposisi batu empedu di Departemen Biokimia dan Biologi Molekuler Fakultas Kedokteran Universitas Indonesia dalam periode 3 tahun terakhir, yaitu tahun 2017 hingga Agustus 2019. Usia termuda yang menjadi sampel penelitian ini, yaitu 11 tahun dan usia tertua, yaitu 79 tahun.

Analisis komposisi batu empedu dilakukan dari $1 \mathrm{~g}$ batu empedu yang digerus dengan $10 \mathrm{~mL}$ eter kemudian disaring untuk mendapatkan filtrat. Sebanyak $5 \mathrm{~mL}$ alkohol ditambahkan pada setengah volume dari filtrat yang diperoleh, kemudian dibiarkan menguap sampai kering. Kristal kolesterol dapat diperiksa dengan menggunakan mikroskop/ dengan uji Salkowski. Residu yang terbentuk dapat dimanfaatkan untuk pengujian karbonat, kalsium, Fe, pigmen empedu dan fosfat. Pemeriksaan karbonat dilakukan dengan melihat pembentukan gas karbon dioksida yang terbentuk dari ion karbonat yang direaksikan dengan larutan $\mathrm{HCl}$. Pemeriksaan kalsium dilakukan dengan mereaksikan kalsium dengan ammonium oksalat. Pemeriksaan $\mathrm{Fe}^{2+}$ dilakukan dengan mereaksikan besi dengan larutan kalium ferosianida. Pemeriksaan pigmen empedu dilakukan dengan melarutkan bilirubin dengan menggunakan kloroform. Pemeriksaan fosfat dilakukan dengan menambahkan urea lalu direaksikan dengan ferrosulfat.
Penelitian ini telah lulus kaji etik oleh Komite Etik Penelitian Fakultas Kedokteran Universitas Indonesia dengan nomor KET-046/UN2.F1.D1.2/ PDP. 01.Riset-2/2019. Data dianalisis dengan menggunakan Statistical Product and Service Solutions (SPSS) tipe 20, kemudian melalui proses editing, coding, dan entry. Setelah itu dilakukan uji hipotesis menggunakan uji Chi square untuk melihat hubungan antara jenis kelamin dengan komposisi batu empedu. Untuk melihat hubungan antara kelompok usia dengan komposisi kolesterol, kalsium, dan karbonat menggunakan uji Chi square sedangkan kelompok usia dengan komposisi Fe, pigmen empedu dan fosfat menggunakan uji Mann whitney karena tidak dapat memenuhi kriteria uji Chi square.

\section{Hasil}

\section{Distribusi Batu Empedu berdasarkan Kelompok Usia dan Jenis Kelamin}

Dari hasil distribusi batu empedu (Tabel 1) terlihat bahwa batu empedu paling banyak terjadi pada kelompok usia 40-49 tahun, yaitu 62 orang dan yang paling sedikit terjadi pada kelompok usia $<$ 20 tahun. Berdasarkan jenis kelamin, batu empedu paling banyak terjadi pada perempuan bila dibandingkan dengan lakilaki. Pada perempuan ditemukan 146 orang dan laki-laki 84 orang.

Tabel 1. Distribusi Batu Empedu berdasarkan Usia dan Jenis Kelamin

\begin{tabular}{|c|c|c|c|}
\hline \multicolumn{3}{|c|}{ Kelompok } & \multirow[t]{2}{*}{ Jumlah } \\
\hline Usia & & $(\%)$ & \\
\hline & $<20$ tahun & & $6(2,6)$ \\
\hline & $20-29$ tahun & & $17(7,4)$ \\
\hline & $30-39$ tahun & & $46(20,0)$ \\
\hline & $40-49$ tahun & & $62(27,0)$ \\
\hline & $50-59$ tahun & & $55(23,9)$ \\
\hline & $\geq 60$ tahun & & $44(19,1)$ \\
\hline & Jenis Kelamin & $(\%)$ & Jumlah \\
\hline & Laki-laki & & $84(36,5)$ \\
\hline & Perempuan & & $146(63,5)$ \\
\hline & Total & & $230(100)$ \\
\hline
\end{tabular}




\section{Distribusi Komposisi Batu Empedu}

Dari hasil distribusi komposisi batu empedu (Tabel 2) terlihat bahwa distribusi komposisi batu empedu yang paling banyak ditemukan merupakan komposisi campuran, yaitu komposisi yang terdiri lebih dari satu komposisi penyusun. Terdapat $227(98,7 \%)$ orang yang memiliki komposisi campuran dalam batu empedunya dan hanya $3(1,3 \%)$ orang yang memiliki komposisi murni, yaitu 2 orang batu kolesterol murni dan 1 orang batu karbonat murni.

Tabel 2. Distribusi Komposisi Batu Empedu

\begin{tabular}{lcc}
\hline & $\mathrm{n}$ & $\%$ \\
\hline Batu murni & 3 & 1,3 \\
Batu kolesterol murni & 2 & 0,9 \\
Batu kalsium murni & - & - \\
Batu karbonat murni & 1 & 0,4 \\
Batu Fe murni & - & - \\
Batu pigmen empedu murni & - & - \\
Batu Fosfat Murni & - & - \\
Batu campuran & 227 & 98,7 \\
\hline
\end{tabular}

\section{Distribusi Komposisi Batu Empedu berdasarkan Kelompok Usia dan Jenis Kelamin}

Komposisi terbanyak yang ditemukan adalah komposisi kolesterol pada perempuan dan laki-laki. Berdasarkan kelompok usia kolesterol banyak ditemukan di kelompok usia 40-
49 tahun dan 50-59 tahun pada perempuan sedangkan laki-laki banyak ditemukan di kelompok usia 40-49 tahun. Komposisi batu empedu yang paling sedikit ditemukan adalah komposisi fosfat baik pada perempuan maupun pada laki-laki (Tabel 3).

Tabel 3. Distribusi Komposisi Batu Empedu berdasarkan Kelompok Usia dan Jenis Kelamin

\begin{tabular}{|c|c|c|c|c|c|c|c|}
\hline & & Kolesterol & Kalsium & Karbonat & $\mathrm{Fe}$ & $\begin{array}{c}\text { Pigmen } \\
\text { Empedu }\end{array}$ & Fosfat \\
\hline & & $\mathrm{n}$ & $\mathrm{n}$ & $\mathrm{n}$ & $\mathrm{n}$ & $\mathrm{n}$ & n \\
\hline \multirow[t]{6}{*}{ Perempuan } & $<20$ & 2 & 3 & 1 & 3 & 2 & 0 \\
\hline & $20-29$ & 11 & 5 & 8 & 9 & 9 & 4 \\
\hline & $30-39$ & 27 & 20 & 17 & 23 & 26 & 6 \\
\hline & $40-49$ & 30 & 22 & 23 & 21 & 25 & 6 \\
\hline & $50-59$ & 30 & 27 & 30 & 30 & 26 & 8 \\
\hline & $\geq 60$ & 23 & 21 & 15 & 26 & 20 & 10 \\
\hline \multirow[t]{6}{*}{ Laki-laki } & $<20$ & 1 & 1 & 1 & 1 & 2 & 0 \\
\hline & $20-29$ & 6 & 5 & 4 & 4 & 3 & 2 \\
\hline & $30-39$ & 16 & 10 & 10 & 13 & 10 & 4 \\
\hline & $40-49$ & 24 & 23 & 12 & 22 & 21 & 7 \\
\hline & $50-59$ & 13 & 10 & 12 & 14 & 11 & 5 \\
\hline & $\geq 60$ & 10 & 11 & 9 & 12 & 12 & 4 \\
\hline \multicolumn{2}{|c|}{ Total } & 193 & 158 & 142 & 178 & 167 & 56 \\
\hline
\end{tabular}


Hubungan Komposisi Batu Empedu terhadap Kelompok Usia dan Jenis Kelamin

Dari hasil analisis secara statistik menggunakan uji Chi square untuk menguji hubungan antara komposisi kolesterol, kalsium, dan karbonat terhadap kelompok usia. Dari hasil tersebut menunjukkan terdapat hubungan $(\mathrm{p}<0,05)$ antara kelompok usia terhadap kejadian komposisi kolesterol dalam batu empedu. Namun tidak ada hubungan $(p>0,05)$ antara kelompok usia terhadap komposisi kalsium dan karbonat. Hasil uji statistik menggunakan uji Mann whitney untuk menguji hubungan antara komposisi $\mathrm{Fe}$, pigmen empedu, dan fosfat terhadap kelompok usia didapatkan nilai yang tidak signifikan $(p>0,05)$ (Tabel 4).

Tabel 3. Hasil Statistik Kelompok Usia terhadap Komposisi Batu Empedu

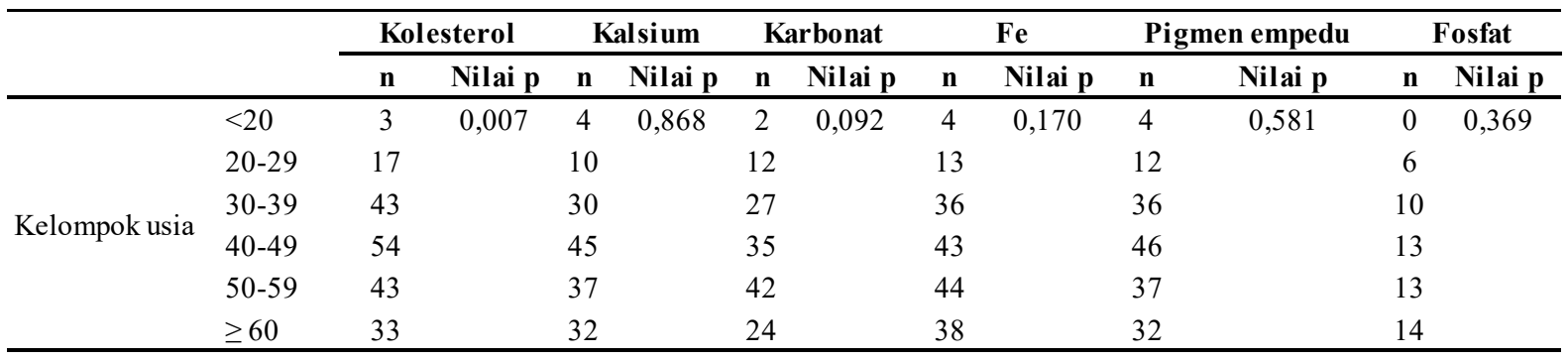

Dari hasil analisis statistik dengan uji Chi square menunjukkan nilai yang tidak signifikan $(p>0,05) \quad$ antara perempuan dan laki-laki terhadap kejadian komposisi kolesterol, kalsium, karbonat, $\mathrm{Fe}$, pigmen empedu, dan fosfat dalam batu empedu. Artinya bahwa tidak terdapat hubungan antara jenis kelamin dengan komposisi kolesterol, kalsium, karbonat, $\mathrm{Fe}$, pigmen empedu, dan fosfat dalam batu empedu (Tabel 5).

Tabel 4. Hasil Uji Statistik antara Jenis Kelamin terhadap Komposisi Batu Empedu

\begin{tabular}{|c|c|c|c|c|c|c|c|c|c|c|c|c|c|}
\hline & & \multicolumn{2}{|c|}{ Kolesterol } & \multicolumn{2}{|c|}{ Kalsium } & \multicolumn{2}{|c|}{ Karbonat } & \multicolumn{2}{|c|}{$\mathbf{F e}$} & \multicolumn{2}{|c|}{ Pigmen Empedu } & \multicolumn{2}{|c|}{ Fosfat } \\
\hline & & $\mathbf{n}$ & Nilai $p$ & $\mathrm{n}$ & Nilai $p$ & $\mathrm{n}$ & Nilai $p$ & $\mathbf{n}$ & Nilai $p$ & $\mathbf{n}$ & Nilai $p$ & $\mathbf{n}$ & Nilai $p$ \\
\hline \multirow{2}{*}{ Jenis Kelamin } & Perer & 123 & 0,856 & 98 & 0,498 & 94 & 0,277 & 112 & 0,746 & 108 & 0,541 & 34 & 0,621 \\
\hline & Laki-laki & 70 & & 60 & & 48 & & 66 & & 59 & & 22 & \\
\hline
\end{tabular}

\section{Pembahasan}

Dalam penelitian ini menunjukkan bahwa kolesterol merupakan penyusun komposisi batu empedu yang paling banyak ditemukan. Hasil ini juga sama dengan hasil penelitian dari Jarrar di Arab Saudi, Arab Saudi bagian Barat, dan Jerman. ${ }^{2,10}$ Namun hasil ini berbeda dari penelitian yang dilakukan dari Sub-Sahara Afrika dan Cina. ${ }^{2,11,12}$ Perbedaan ini kemungkinan dapat disebabkan oleh 
abnormalitas metabolisme dari kolesterol dan perbedaan diet yang dilakukan dari setiap negara. Pembentukan batu empedu yang mengandung kolesterol ini memiliki hubungan dengan tingginya asupan karbohidrat, yang dapat mencetuskan supersaturasi kolesterol dalam empedu. ${ }^{2}$ Hasil komposisi batu empedu pada penelitian ini didominasi oleh lebih dari satu komposisi batu empedu. Hal ini terjadi karena empedu merupakan cairan campuran yang mengandung garam empedu, kolesterol, fosfolipid, bilirubin, elektrolit, dan anion organik sehingga hal ini yang memungkinkan terbentuknya batu empedu campuran. Hal ini juga sama seperti dalam penelitian oleh Weerakon di Sri Lanka. Pada penelitiannya juga ditemukan bahwa komposisi batu empedu paling banyak ditemukan adalah campuran antara beberapa komposisi dan hanya sedikit yang hanya memiliki satu komposisi di dalam batu empedunya. ${ }^{13}$

Berdasarkan hasil penelitian ini, kejadian batu empedu paling banyak terjadi pada kelompok usia 45 - 64 tahun. Kejadian ini sesuai dengan penelitian sebelumnya yang menyatakan bahwa kejadian batu empedu meningkat dengan bertambahnya usia. Peningkatan tajam terjadi setelah usia 40 tahun, yaitu menjadi 4 - 10 kali lebih rentan pada individu yang lebih tua. ${ }^{2,14,15}$ Hal ini terjadi karena jumlah kolesterol pada kandung empedu mengalami peningkatan. Peningkatan jumlah kolesterol ini dapat disebabkan oleh berkurangnya sintesis asam empedu karena menurunnya aktivitas enzim cholesterol-7a-hidroxylase (CYP7A1). ${ }^{7,15}$ Enzim ini berperan dalam pengubahan kelebihan kolesterol hati menjadi asam empedu melalui jalur klasik. ${ }^{16-18}$

Pada penelitian ini menunjukkan bahwa kejadian batu empedu lebih banyak terjadi pada perempuan, dengan perbandingan perempuan : laki-laki yaitu 1,7 : 1. Hasil ini didukung oleh beberapa penelitian sebelumnya yang menyatakan bahwa perempuan lebih rentan terkena batu empedu dari pada laki-laki. Dalam penelitian yang dilakukan di Arab Saudi, India, dan Pakistan menyebutkan bahwa perempuan lebih banyak menderita penyakit batu empedu daripada lakilaki. ${ }^{2,19,20}$ Hal ini terjadi kemungkinan karena adanya perbedaan hormon dasar antara laki-laki dan perempuan. Beberapa ahli berhipotesis bahwa hormon estrogen yang lebih banyak ditemukan pada perempuan dibandingkan pada laki-laki memiliki peran penting dalam pembentukan batu empedu. ${ }^{2,7,21}$ Hormon ini dapat menurunkan kadar low-density lipoprotein (LDL) plasma dan meningkatkan high-density lipoprotein (HDL) plasma karena kadar estradiol yang tinggi akan memperkuat ekspresi reseptor HDL dan reseptor LDL. Penurunan LDL plasma merupakan hasil dari peningkatan ekspresi reseptor LDL hati yang akan meningkatkan clearance LDL plasma. Oleh karena itu, peningkatan penyerapan LDL oleh hati dapat menyebabkan peningkatan sekresi kolesterol dalam empedu. $^{22}$ Selain itu perempuan yang sedang hamil juga memiliki potensi lebih tinggi untuk terkena batu empedu. Hal ini dibuktikan dalam penelitian yang dilakukan oleh Jarrar di Arab Saudi. Peningkatan kadar sex hormon saat hamil kemungkinan dapat meningkatkan kolesterol dalam empedu dan mengurangi pergerakan kandung empedu sehingga dapat menyebabkan batu empedu. ${ }^{2,7}$

Pada penelitian ini menunjukkan bahwa terdapat hubungan antara kelompok usia dengan komposisi kolesterol. Hasil ini berbeda dari penelitian yang dilakukan oleh Schafmayer et al di Jerman yang menunjukkan hasil bahwa usia memiliki korelasi yang tidak terlalu kuat terhadap komposisi batu $(\mathrm{p}=0,045)$. Akan tetapi pada penelitian ini menunujukkan hasil yang kuat $(p=0,007)$ terhadap korelasi usia dengan komposisi kolesterol. Perbedaan ini kemungkinan dapat dikarenakan oleh jumlah data yang digunakan dan pola diet dari pasien di setiap negara yang berbeda. Pada penelitian tersebut menggunakan 
jumlah sampel sebanyak $1074 .{ }^{11}$ Selain itu, hasil penelitian ini menunjukkan tidak terdapat hubungan antara kelompok usia dengan komposisi kalsium, karbonat, Fe, pigmen empedu, dan fosfat dalam batu empedu. Hasil ini pun berbeda dengan penelitian yang dilakukan oleh Qiao di Cina. Dalam penelitian tersebut dibuktikan bahwa komposisi batu empedu pada usia tua lebih banyak mengandung komposisi pigmen, kalsium karbonat, dan fosfat dibandingkan dengan komposisi kolesterol. Perbedaan ini kemungkinan dapat disebabkan oleh jumlah sampel yang berbeda. Pada penelitian yang dilakukan oleh Qiao jumlah sampel yang digunakan sebanyak 807 sedangkan pada penelitian saat ini hanya menggunakan 230 sampel. Selain itu perbedaan dari metode diagnosis yang digunakan dalam menganalisis komposisi yang terdapat dalam batu empedu kemungkinan juga dapat menjadi alasan dari perbedaan hasil yang didapatkan. Pada penelitian yang dilakukan oleh Qiao, metode diagnosis yang digunakan adalah Fourier Transform Infrared Spectroscopy (FTIR). ${ }^{23}$

Hasil penelitian ini menunjukkan tidak terdapat hubungan antara jenis kelamin terhadap tiap komposisi batu empedu. Hasil ini menunjukkan kemiripan dengan penelitian yang dilakukan oleh Tsai di China. Dalam penelitian tersebut menyebutkan bahwa tidak ada perbedaan yang signifikan antara jenis kelamin terhadap jenis batu empedu. ${ }^{13}$ Namun hasil ini pun berbeda dari penelitian yang dilakukan oleh Qiao di Cina. Pada penelitian tersebut menyebutkan bahwa proporsi perempuan dalam komposisi kolesterol dan kalsium stearat lebih tinggi signifikan dari pada proporsi laki-laki. Perbedaan ini dapat disebabkan pula oleh perbedaan jumlah sampel yang digunakan. Selain itu perbedaan ini juga dapat disebabkan oleh kebiasaan diet yang berbeda di setiap negara. ${ }^{23}$
Distribusi komposisi batu empedu yang paling banyak ditemukan dari hasil data Laboratorium Departemen Biologi dan Biokimia FKUI yaitu kolesterol serta paling banyak terjadi pada perempuan kelompok usia $40-49$ tahun. Terdapat hubungan antara komposisi kolesterol dengan kelompok usia namun tidak terdapat hubungan antara komposisi batu empedu dengan jenis kelamin.

\section{Saran}

Penelitian selanjutnya diperlukan untuk menilai analisis pola diet dan status kehamilan pada subjek penelitian untuk melihat pengaruhnya terhadap komposisi batu empedu. Selain itu, analisis komposisi batu empedu diukur secara kuantitatif sehingga dapat ditentukan jenis batu empedu secara tepat.

\section{Daftar Rujukan}

1. Jameson JL, Kasper DL, Longo DL, Fauci AS, Hauser SL, Loscalzo J, editor. Harrison's : principles of Internal Medicine. 20 ed. Vol. 1. New York: Mc Graw Hill Education; 2018. 2423.

2. Jarrar BM, Al-Rowaili MA. Chemical composition of gallstones from Al-jouf province of saudi arabia. Malays J Med Sci MJMS. April 2011;18(2):47-52.

3. Koivusalo A, Pakarinen M, Gylling H, Nissinen MJ. Relation of cholesterol metabolism to pediatric gallstone disease: a retrospective controlled study. BMC Gastroenterol. Desember 2015;15(1):74.

4. Pradhan S, Joshi M, Vaidya A. Prevalence of different types of gallstone in the patients with cholelithiasis at Kathmandu Medical College, Nepal. Kathmandu Univ Med J. 2009;7(3):26871.

5. Stinton LM, Shaffer EA. Epidemiology of Gallbladder Disease: Cholelithiasis and Cancer. Gut Liver. 15 April 2012;6(2):172-87.

\section{Kesimpulan}


6. Fryar CD, Ahluwalia N. Fast Food Consumption Among Adults in the United States, 2013-2016. 2018;(322):8.

7. Yoo E-H, Lee S-Y. The prevalence and risk factors for gallstone disease. Clin Chem Lab Med. 1 Januari 2009;47(7).

8. Chen C-H, Huang M-H, Yang J-C, Nien C-K, Etheredge GD, Yang C-C, dkk. Prevalence and risk factors of gallstone disease in an adult population of Taiwan: an epidemiological survey. J Gastroenterol Hepatol. November 2006;21(11):1737-43.

9. Wang Y, Wang L, Xue H, Qu W. A Review of the Growth of the Fast Food Industry in China and Its Potential Impact on Obesity. Int J Environ Res Public Health. 9 November 2016;13(11):1112.

10. Hendrik K. Pola distribusi pasien kolelitiasis di rsu dr. soedarso Pontianak periode januari 2010-desember 2011. [Pontianak]: Universitas Tanjungpura; 2013.

11. Schafmayer C, Hartleb J, Tepel J, Albers S, Freitag S, Völzke H, dkk. Predictors of gallstone composition in 1025 symptomatic gallstones from Northern Germany. BMC Gastroenterol. Desember 2006;6(1):36.

12. Iii FFA, Takongmo S, Griffith D. Determination of chemical composition of gall bladder stones: Basis for treatment strategies in patients from Yaounde, Cameroon. World J Gastroenterol. 2004;10(2):303.

13. Tsai W-L. Composition of common bile duct stones in Chinese patients during and after endoscopic sphincterotomy. World J Gastroenterol. 2005;11(27):4246.

14. Weerakoon H, Navaratne A, Ranasinghe S, Sivakanesan R, Galketiya KB, Rosairo S. Chemical Characterization of Gallstones: An Approach to Explore the Aetiopathogenesis of
Gallstone Disease in Sri Lanka. Mittal B, editor. PLOS ONE. 8 April 2015;10(4):e0121537.

15. Reshetnyak VI. Concept of the pathogenesis and treatment of cholelithiasis. 2012;4(2):17.

16. Shabanzadeh DM. Incidence of gallstone disease and complications: Curr Opin Gastroenterol. 2018;34(2):81-9.

17. Kosters A, Jirsa M, Groen AK. Genetic background of cholesterol gallstone disease. Biochim Biophys Acta BBA - Mol Basis Dis. 2003;1637(1):1-19.

18. Chiang JYL. Regulation of bile acid synthesis: pathways, nuclear receptors, and mechanisms. J Hepatol. 2004;40(3):539-51.

19. Chandran P, Kuchhal NK, Garg P, Pundir CS. An extended chemical analysis of gallstone. Indian J Clin Biochem. September 2007;22(2):145-50.

20. Channa NA, Khand FD, Khand TU, Leghari MH, Memon AN. Analysis of human gallstone by fourier transform infrared (FTIR). Malays J Anal Sci. 2008;12(3):552-60.

21. Cao AM, Eslick GD. Epidemiology and Pathogenesis of Gallstones. Dalam: The management of gallstone disease. Switzerland: Springer; 2018. hlm. 53-61.

22. Wang HH, Liu M, Clegg DJ, Portincasa P, Wang DQ-H. New insights into the molecular mechanisms underlying effects of estrogen on cholesterol gallstone formation. Biochim Biophys Acta BBA - Mol Cell Biol Lipids. November 2009;1791(11):1037-47.

23. Qiao T, Ma R, Luo X, Yang L, Luo Z, Zheng P. The Systematic Classification of Gallbladder Stones. Wang Y, editor. PLoS ONE. 4 Oktober 2013;8(10):e74887. 